\title{
Mapping energy crop cultivation and identifying motivational factors among Swedish farmers
}

\author{
Madelene Ostwald, Anna Jonsson, Victoria Wibeck and Therese Asplund
}

\section{Linköping University Post Print}

\section{Tweet}

N.B.: When citing this work, cite the original article.

Original Publication:

Madelene Ostwald, Anna Jonsson, Victoria Wibeck and Therese Asplund, Mapping energy crop cultivation and identifying motivational factors among Swedish farmers, 2013, Biomass and Bioenergy, (50), , 25-34.

http://dx.doi.org/10.1016/j.biombioe.2012.09.058

Copyright: Elsevier

http://www.elsevier.com/

Postprint available at: Linköping University Electronic Press

http://urn.kb.se/resolve?urn=urn:nbn:se:liu:diva- 86210 


\section{MAPPING ENERGY CROP CULTIVATION AND IDENTIFYING MOTIVATIONAL FACTORS AMONG SWEDISH FARMERS}

Article Type: Research Paper

Madelene Ostwalda; Anna Jonsson ${ }^{b}$; Victoria Wibeck ${ }^{c}$; Therese Asplund ${ }^{d}$

aCentre for climate science and policy research, The Tema Institute, Linköping University, 60174

Norrköping, Sweden, Phone: +46-11-363149, Fax: +46-11-363292, email: madelene.ostwald@liu.se

b Centre for climate science and policy research, The Tema Institute, Linköping University, 60174

Norrköping, Sweden, Phone: +46-11-363234, Fax: +46-11-363292, email: anna.c.jonsson@liu.se

c Centre for climate science and policy research, The Tema Institute, Linköping University, 60174 Norrköping, Sweden, Phone: +46-11-363285, Fax: +46-11-363292, email: victoria.wibeck@liu.se

d Centre for climate science and policy research, The Tema Institute, Linköping University, 60174 Norrköping, Sweden, Phone: +46-11-363397, Fax: +46-11-363292, email: therese.asplund@liu.se

Corresponding Author: Dr Madelene Ostwald 


\section{ABSTRACT}

Based on a meta-study, the paper describes the existing options, areal extents, and Swedish farmers' conditions for energy crop production promoted by the governments to mitigate and adapt to climate change. The drivers of and barriers to cultivating various energy crops are described in terms of a variety of motivational factors. The approach used peer-reviewed and grey literature using three internet sources. Questions addressed include the energy crops available to Swedish farmers and how well established they are in terms of areal extent. What drivers of and barriers to growing energy crops do farmers perceive? How do various motivational factors for these drivers and barriers correspond to the adoption of certain energy crops? The results indicate that 13 energy-related crops are available, of which straw (a residue), oil crops, and wheat are the most extensively produced in terms of cultivated area. Results confirm earlier research findings that converting from annual to perennial crops and from traditional crops or production systems to new ones are important barriers. Economic motivations for changing production systems are strong, but factors such as values (e.g., aesthetics), knowledge (e.g., habits and knowledge of production methods), and legal conditions (e.g., cultivation licenses) are crucial for the change to energy crops. Finally, there are knowledge gaps in the literature as to why farmers decide to keep or change a production system. Since the Swedish government and the EU intend to encourage farmers to expand their energy crop production, this knowledge of such motivational factors should be enhanced.

Key words: land-use change, drivers, barriers, farmers' incentives, energy crop cultivation, crop residue 


\section{INTRODUCTION}

The national intention to convert Swedish energy use from fossil fuels to renewable energy has been reinforced by the climate change debate and the general acceptance of the concept of sustainable development. As a member of the European Union (EU), Sweden has since 2007 had an overall binding target of converting its existing energy supply to $20 \%$ renewable by 2020 [1]. Furthermore, the EU has set a binding target that at least $10 \%$ of gasoline and diesel consumed in the transport sector should be from bioenergy by 2020. As for all member states, Sweden's target have been adapted to national circumstances. Sweden's target was set at $49 \%$ of total consumed energy from renewable sources by 2020 (up from 39.8\% in 2005) - the highest proportion of any of the 27 member states [2]. Due to climate change, the temperature is projected to increase by up to $7^{\circ} \mathrm{C}$ in northern Sweden and precipitation patterns are expected to change, with more rainfall expected in the west than in the drier east [3]. Consequently, Swedish agriculture will be exposed to increased risk of damage from insects, fungi and viruses and new demands for irrigation and drainage systems [4]. Greenhouse gas (GHG) emissions from agriculture in Sweden in 2007 were reported as $8.54 \mathrm{Tg}$ of carbon dioxide equivalents $\left(\mathrm{CO}_{2}\right.$ eq.), while lowered to 8.47 in 2008 [5] contributing to less than $10 \%$ of national total emissions [6]. These figures mean that Swedish agriculture emits less than $0.1 \%$ of the total global land use $\mathrm{CO}_{2}$ emissions (6 Pg y-1) [7]. Despite Sweden's small contribution in global terms, there are demands for the agriculture sector to change. Producing more energy-related products or energy crops on traditional agricultural land, i.e., "energy farming" [8], is one strategy. Producing energy crops could reduce emissions from the land [9] and offset GHG by replacing the use of fossil fuel. At present, approximately $2 \%$ of Sweden's arable land is used for energy production [10]. Several studies indicate that energy crop production from the agricultural sector will increase in the future $[3,11]$. The Swedish agricultural sector produced the equivalent of 1-1.5 TWh in $2006[3,12]$. From model runs [4], it has been calculated that agriculture could contribute with 15-30 TWh depending on the economic and political measures put in place. The Federation of Swedish Farmers (LRF) has made a committed to increasing this to at least 5 TWh 
in the near future [13]. A great potential for increases in energy crop cultivation has also been identified at the European level $[8,14]$.

The United Nations Framework Convention on Climate Change (UNFCCC) along with international organizations such as the International Energy Agency (IEA) and the Food and Agriculture Organization (FAO) argue that bioenergy is a key strategy to mitigate climate change [15]. At the same time, the inherent problem in using limited land resources to produce renewable energy in a situation of high commodity prices and continuously growing world population should not be underestimated. It has been argued that especially in developing countries, there is a risk for 'further exploitation of poor regions rather than providing them benefits' [16]. Large-scale conversion of land for food and feed production into sites for production of bioenergy crops may have negative social and ecological effects e.g. as regards to food security, subsistence of small-scale farmers and preservation of biodiversity [17]. Still, production of energy crops is one important strategy to mitigate GHG emissions by replacing the use of fossil fuels.

Earlier studies of the conditions necessary for land use or production change at the Swedish and international levels have demonstrated the importance of economic incentives for the individual actor $[18,19]$. For the Swedish case, economic evaluations of investment in energy crop production yield contradictory results. Despite the potential profit, existing subsidies, and relatively large interest on the part of farmers in energy crop cultivation [18], the extent of agricultural energy crop production remains rather limited [20,21]. Moreover, there are many varieties of energy crops to chose from, each with their own particular cultivation opportunities and limitations and sets of drivers and barriers.

This paper aims to improve our understanding of the preconditions for farmers to begin producing energy crops, which serve both climate change mitigation and adaptation purposes. The specific research questions are: i) What energy crops are available to Swedish farmers and how well established are they in areal extent? ii) What drivers of and barriers to growing energy 
crops do farmers perceive? iii) How do various motivational factors underlying the drivers and barriers relate to the adoption of selected energy crops?

This paper's findings form the basis of a framework for research (namely the project competitively strengthened agriculture communication about climate change and new possibilities conducted from Linköping University) into the communication and hence motivational factors underlying farmers' land use choices in relation to energy crops. The results will highlight the knowledge gap concerning why farmers choose to change their land use, including motivational factors. In terms of increasing energy crop production - a Swedish government goal - our analysis also serves as a basis for policy decisions regarding the enhancement of drivers and removal of barriers.

\section{MOTIVATIONAL FACTORS AS DRIVERS AND BARRIERS - EARLIER}

\section{STUDIES}

Through an economic assessment of various production options for arable land, Börjesson [9] found that energy crop production would give the farmer a higher net profit than would traditional production, primarily through reduced costs. However, in a choice experiment-study including grain, reed canary grass (Phalaris arundinacea), hemp (Cannabis sativa) and salix (Salix is a genus and refer to species such as willow and sallow), Paulrud and Laitila [18] found that a compensation of up to $215 €$ ha-1 $^{-1}$ conversion rate (March 18, 2011): $1 €=9,31$ SEK) would be necessary for a farmer to convert from a traditional crop to salix. These differences in results, apart from obvious changes in market conditions between 1999 and 2007, likely depend on the particular drivers and barriers included in the studies. Berg et al. [11] pinpointed the lack of standardized calculation methods for short- and long-term comparisons between traditional and energy crops; in particular overhead costs are treated differently. Paulrud and Laitila [18] included five factors apart from net profit: form of cultivation (contract or not), flexibility of land use (annual, 10 or 20 years), traditional cultivation technology (yes or no), landscape effects 
(height of $<2,2-4$ or 4-8 m), and subsidies (yes or no). The present paper is more explorative in investigating whether these factors are the most important, and what other factors may influence farmer decisions.

Despite the potential profit, existing subsidies, and relatively strong interest from farmers in energy crop cultivation [18], the extent of such production is rather limited [21]. Except from Paulrud and Laitila [18], who include non-economical incentives converted into monetary terms, it seems that earlier studies have focused on economic incentives, and that these alone cannot explain farmer behavior. Domac et al. [14] found that focus on the quantification of economic incentives also guides much general research into the implementation of bio-energy projects, leaving a knowledge gap regarding the involved social, cultural, institutional, and environmental issues from the individual actor's point of view.

Studies of the public understanding of environmental issues have demonstrated that there is often a gap between peoples' opinions and actions $[22,23]$. This means that although actors may know about environmental issues, they might not act in ways that contribute to environmental sustainability [24]. The reasons for this vary, possibly because many environmental problems are characterized by complexity and uncertainty, often being global in character and with effects that are distant in time and space $[23,25]$. Hence, it is important to analyze not only actors' stated opinions, but also the barriers preventing people from taking action as well as the drivers encouraging them to do so $[23,24]$.

Barriers and potentials and hence motivational factors for actors to engage in environmental protection measures can also be applied in analyzing farmers' choices in terms of engaging in energy crop production. Trudgill [26] identified six types of barriers namely, agreement, knowledge, technological, economic, social and political, and administrative barriers, as hindering increased energy crop cultivation. The Global International Water Assessment (GIWA)-approach [27] addresses four institutional layers that together form the decision context for decision-makers in water management, namely, socio-cultural rules, formal rules of 
the game, governance rules, and resource allocation mechanisms. Price incentives on the market for energy crops (traditional and/or new) could change instantly if new circumstances arose (e.g., increased/decreased wheat demand for energy production or changed global food prices). In comparison, Blennow and Persson [28] found that, among Swedish private forest owners another type of land users, adaptation to climate change was influenced by their belief in climate change. Furthermore, individuals who had not adapted to climate change, even though they believed in it, expressed a lack of understanding of how they could adapt or a lack of belief in the available ways to adapt. Although there has been little or no research into the links between belief in climate change and knowledge of adaptation measures among Swedish farmers, their attitudes and behavior likely resemble those of the studied forest owners.

Furthermore, drivers and barriers can be separated into the proximate causes and underlying driving forces of individual decisions regarding land use changes [19]. Proximate causes are the motivational factors directly experienced by farmers; for example, increased demand for a product on an available market driving a change in land use. Underlying driving forces are indirect and more process oriented, such as climate change.

This paper aims to identify a range of barriers and drivers by conducting a content analysis of a predefined body of grey and peer-reviewed literature. These barriers and drivers will be categorized into four broad groups of motivational factors; i.e., values, legal, knowledge and economic factors. All these factors are important to farmers making decisions regarding whether or not to produce energy crops. We also aim to explore to what extent each type of motivational factor likely serves as a driver of or barrier to the adoption of certain energy crops.

\section{METHODS}

This meta-study builds on other Swedish studies of energy crop production that drew on both the peer-reviewed and grey literature. Our method involved three literature searches: i) Google 
scholar search motor for peer-reviewed studies, ii) The Swedish government's portal for official reports (i.e., Swedish Government Official Reports so called SOUs), and iii)

www.bioenergiportalen.se, a portal for sector organizational reports. Our search included the words bioenergy, energy crop, agriculture, attitude, and Sweden, and covered the 1990-October 2009 period. The search was done in January 2010. If the located documents mentioned any of the following - assessment of energy crop extent, condition, and rationale (versus, e.g., biogas production, phenological tests, energy output, and solar energy), information on crops grown in Sweden, information on reasons for choosing whether or not to grow energy crops (i.e., motivational factors), or farmers characteristics - the document was regarded as relevant to the analysis and was included. A full list of the material found via the different searches is given in Appendix A.

In the study, we have chosen to use the concept "energy crop" in the meaning of crops cultivated both for direct (i.e., hemp, willow etc.) and indirect energy generation (i.e., grains that can be used in ethanol production). In this definition of energy crop, we also include residues from other crops, such as for example straw.

\section{RESULTS}

\subsection{ENERGY CROPS AVAILABLE FOR SWEDISH FARMERS}

According to the data found in the meta-study, 13 energy crops are available to Swedish farmers today (Table 1). Of these 13 crops, straw (a field residue of cereal production and not a crop per se) covers the largest area, i.e., 30, 000 ha. Production of this "crop" uses traditional farming practices and subsidies where available for the studied period (even though changes were made in 2010). There are several heating plants burning straw, including two major ones in Skåne. Oil crops and wheat cover approximately 25,000 ha each, mainly in southern Sweden. Here traditional methods are used and subsidies are available for growing these for energy 
production. Salix covers $14-15,000$ ha, with a strong representation around Mälardalen; the production technique for this crop was new in the 1990s and subsidies of $45 €$ ha $^{-1}$ are available. 
Table 1 -Available energy crops in Sweden including annual rotation, areal extent, geographical focus, end use, crop history, and subsidies/market conditions.

\begin{tabular}{|c|c|c|c|c|c|c|}
\hline Crop & $\begin{array}{l}\text { Rotation } \\
\text { (annual) }\end{array}$ & $\begin{array}{l}\text { Areal } \\
\text { (ha) }\end{array}$ & Geog. Focus & End use & Crop history & Subsidies/Market conditions \\
\hline Oil crops & 1 & $>25,000[3]$ & $\begin{array}{l}\text { South (Skåne) } \\
\text { dominates [18] }\end{array}$ & $\begin{array}{l}\text { Biodiesel, } \\
\text { ethanol, and } \\
\text { biogas [29] }\end{array}$ & Traditional & $\begin{array}{l}\text { Rural Prog. Subsidies available for } \\
\text { local systems [3] } \\
\text { Conventional market alternative }\end{array}$ \\
\hline Wheat & 1 & 25,000 & $\begin{array}{l}\text { South (Skåne) } \\
\text { dominates [18] }\end{array}$ & $\begin{array}{l}\text { Ethanol for } \\
\text { transport }\end{array}$ & $\begin{array}{l}\text { Traditional } \\
\text { energy burning, } \\
1980[3]\end{array}$ & Conventional market alternative \\
\hline Oats & 1 & $5000[18]$ & $\begin{array}{l}\text { South (Skåne) } \\
\text { dominates [18] }\end{array}$ & $\begin{array}{l}\text { Heating } \\
\text { (more } \\
\text { benefits than } \\
\text { from wheat) }\end{array}$ & $\begin{array}{l}\text { Traditional } \\
\text { energy burning, } \\
1980[3]\end{array}$ & Conventional market alternative \\
\hline $\begin{array}{l}\text { Hemp } \\
\text { (Cannabis } \\
\text { sativa) }\end{array}$ & 1 & $\begin{array}{l}600 ; 368, \\
{[30] 290[20]}\end{array}$ & $\begin{array}{l}\text { Most parts of } \\
\text { Sweden }[30,31]\end{array}$ & Heating [31] & $\begin{array}{l}\text { Illegal until } \\
2003[20,30, \\
31] \text { used for } \\
\text { energy } \\
\text { production } \\
\text { since } 2007 \text { [18] }\end{array}$ & $\begin{array}{l}\text { EUR } 100 \mathrm{ha}^{-1} \text {; uncertain market } \\
\text { [32] }\end{array}$ \\
\hline $\begin{array}{l}\text { Grass } \\
\text { (prairie + } \\
\text { elephant) }\end{array}$ & 1 & 300 & & Biogas & New & \\
\hline $\begin{array}{l}\text { Sugar beets } \\
\text { (Beta } \\
\text { Vulgaris) }\end{array}$ & 1 & $0[3]$ & $\begin{array}{l}\text { Rarely grown for } \\
\text { energy use [33] }\end{array}$ & $\begin{array}{l}\text { Ethanol and } \\
\text { biogas }\end{array}$ & Traditional & $\begin{array}{l}\text { Production planned to decrease } \\
\text { in area. Subsidies approximately } \\
\text { EUR } 9 \text { M 2006-2010 [3]. } \\
\text { Conventional market alternative }\end{array}$ \\
\hline Corn & 1 & On test [34] & & Biogas & $\begin{array}{l}\text { Traditional. } \\
\text { Inspired from } \\
\text { Germany [34] }\end{array}$ & Conventional market alternative \\
\hline $\begin{array}{l}\text { Straw }(90 \% \\
\text { residual } \\
\text { product) } 4\end{array}$ & 1 & $30,000[3]$ & & $\begin{array}{l}\text { Heating at } \\
\text { farm level. } \\
\text { Widely used } \\
\text { in Denmark } \\
\text { [3] }\end{array}$ & Traditional & $\begin{array}{l}\text { Two district heating plants } \\
\text { (Skåne); approx. } 25 \text { smaller } \\
\text { heating plants [3] } \\
\text { Rural Prog. Subsidies available [3] } \\
\text { Conventional market alternative }\end{array}$ \\
\hline Ley crops & $\begin{array}{l}0.5[34] \text { to } \\
7\end{array}$ & $300[18]$ & & $\begin{array}{l}\text { Heating, } \\
\text { electricity, } \\
\text { transport fuel } \\
\text { [3], and } \\
\text { biogas }\end{array}$ & Traditional & $\begin{array}{l}\text { Primarily for farm level biogas } \\
\text { production } \\
\text { Conventional market alternative }\end{array}$ \\
\hline $\begin{array}{l}\text { Reed canary } \\
\text { grass } \\
\text { (Phalaris } \\
\text { arundinacea) }\end{array}$ & $\begin{array}{l}1 \text { to } 10 \\
{[34]}\end{array}$ & $\begin{array}{l}600[18]- \\
3500[3] \\
\text { (only } \\
\text { fraction for } \\
\text { energy) }\end{array}$ & $\begin{array}{l}\text { North dominates } \\
\text { [34] }\end{array}$ & $\begin{array}{l}\text { Briquettes/ } \\
\text { pellets for } \\
\text { heating }\end{array}$ & New & $\begin{array}{l}\text { Clone development - Bamse [34] } \\
\text { Rural Prog. Subsidies available [3] } \\
\text { No established market }\end{array}$ \\
\hline Salix & $\begin{array}{l}\text { Harvest: } \\
3 \text { [34] to } 6 \\
\text { [35] } \\
\text { Perennial: } \\
20-25[8]\end{array}$ & $\begin{array}{l}14,000- \\
15,000[8, \\
36]\end{array}$ & $\begin{array}{l}\text { South of Dalälven, } \\
\text { Strong in } \\
\text { Mälardalen }\end{array}$ & Heating & Since 1990s [3] & $\begin{array}{l}\text { Subs. EUR } 45 \mathrm{ha}^{-1} \text { [11] agro fuel. } \\
\text { Establishment subs. EUR } 550 \mathrm{ha}^{-1} \\
\text { [37] } \\
\text { Pilot system for ethanol [3] } \\
\text { Potential resource for } 2 \text { nd gen } \\
\text { transport fuel gasification [3] }\end{array}$ \\
\hline $\begin{array}{l}\text { Poplar } \\
\text { (Populus } \\
\text { tremula) }\end{array}$ & $15-20[34]$ & $\sim 100[34]$ & $\begin{array}{l}\text { Plains of Skåne, } \\
\text { Halland, and } \\
\text { Götaland (south) } \\
{[34]}\end{array}$ & & Since 1990s & $\begin{array}{l}\text { Much hybrid development in } \\
\text { N.Am. } \\
\text { Establishment subs. EUR } 550 \text { ha }^{-1} \\
\text { [37] } \\
\text { Rural Prog. Subsidies available [3] }\end{array}$ \\
\hline
\end{tabular}




\begin{tabular}{|l|l|l|l|l|l|l|}
\hline $\begin{array}{l}\text { Hybrid } \\
\text { Aspen } \\
\text { (Populus } \\
\text { tremula L. } x\end{array}$ & $25[34]$ & $100[3]$ & Coast in north & & New & Establishment subs. EUR 550/ha \\
P. \\
tremuloides \\
Michx)
\end{tabular}


As can be seen in Table 1, cultivation areal, geographical focus, and end use vary widely between crops and groups of crops. To some extent, motivational factors related to the history of the crop, i.e., whether it is traditional or new, and existing subsidies and market conditions may explain the differences in areal extent, but the strength of these relationships is not explored in the literature. Biophysical parameters such as climate and soil conditions may account for many of the geographical differences in crop adoption. Paulrud and Laitila's [18] investigation of farmer valuations of the "side effects" of various energy crops inspired us to conduct a qualitative and deeper exploration of the motivational factors that may function as drivers and barriers for farmer choices in this context.

\subsection{MOTIVATIONAL FACTORS FOR PRODUCING ENERGY CROPS - DRIVERS AND BARRIERS}

\section{FROM THE FARMER'S PERSPECTIVE}

Four broad groups of motivational factors relating to values, legal conditions, knowledge, and the economy have been identified (Table 2). Along with these, we found a variety of more specific factors that may serve as drivers of or barriers to individual farmers when considering the adoption of a certain energy crop. 
Table 2 - Identified motivational factors found to determine whether or not farmers engage

\begin{tabular}{|c|c|}
\hline $\begin{array}{l}\text { MOTIVATIONAL } \\
\text { FACTORS }\end{array}$ & POSSIBLE BARRIERS AND DRIVERS \\
\hline Values & 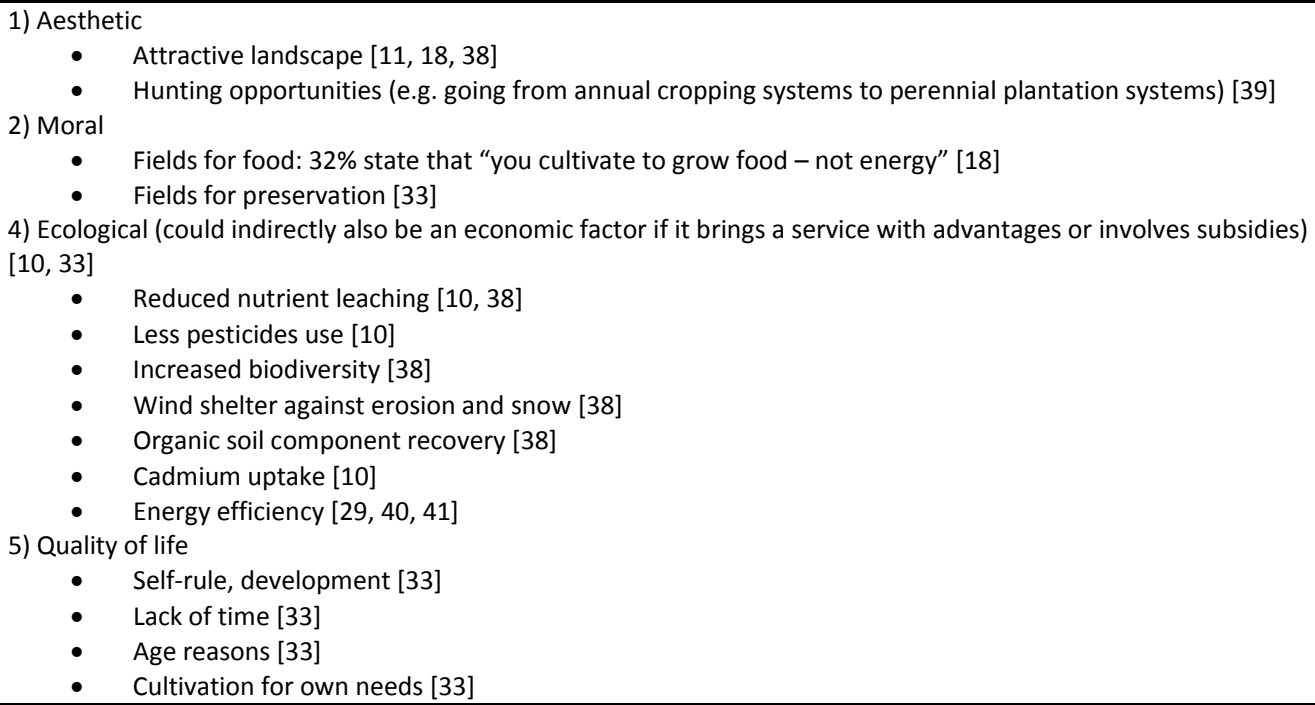 \\
\hline Legal & $\begin{array}{l}\text { 1) Property rights } \\
\bullet \quad \text { Tenure conditions for perennial crops }[8,11,18] \\
\text { 2) Cultivation licence/specification of variety (hemp) }[31,38] \\
\text { 3) Complicated regulation systems [33] }\end{array}$ \\
\hline Knowledge & $\begin{array}{l}\text { 1) Knowledge of cultivation methods }[11,18] \\
\text { 2) Knowledge of alternative crops [11] } \\
\text { 3) Policy support (e.g., research, and extension) }[8,11] \\
\text { 4) Knowledge of the market: access, sell, agreements, and contracts [33] } \\
\text { 5) Energy knowledge [33] } \\
\text { 6) Machines and equipment [30] }\end{array}$ \\
\hline Economy & 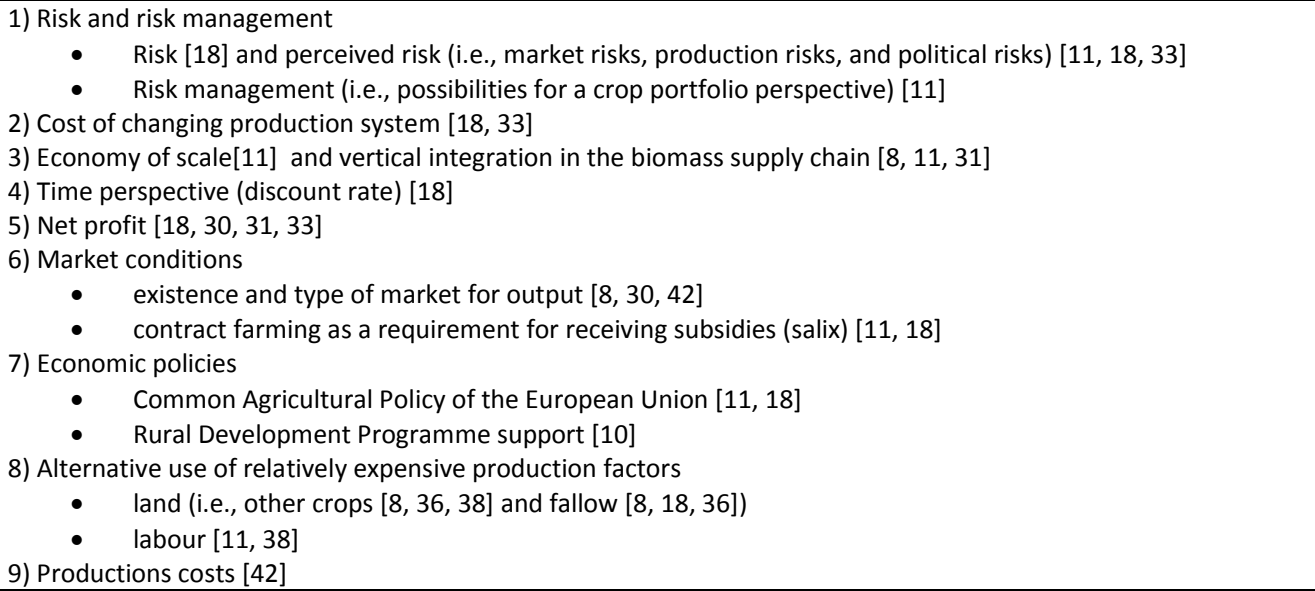 \\
\hline
\end{tabular}


As shown in the Table 2, the four groups of motivational factors include numerous aspects and conditions affecting farmer decisions concerning energy crop adoption. For different types of crops, different motivational factors may exert influence in a positive, neutral, or negative direction, i.e., a certain motivational factors may serve as a barrier to one crop but a driver of another. The results in Table 2 also indicate that research into the reasons why farmers change production systems has been rather limited and often very specific with regard to a certain crop or motivational factor and with a focus on economic factors.

In the following, we aim to identify the relationships existing between types of energy crops and different motivational factors. To structure the analysis, we will use four specific crops to exemplify crop types, namely, cereals that can be used in ethanol production (i.e., wheat), hemp, and salix (also used by Paulrud and Laitila [18]) and the newer perennial crop, hybrid aspen (Populus tremula L. x P. tremuloides Michx.).

The first crop, wheat, is an annual crop that has been cultivated for centuries in Sweden mainly for food and that has largely shaped the economic and technical structure of Swedish farm enterprises, creating a highly valued cultural landscape. The continued cultivation of wheat, but now for energy production, might be associated with various advantages stemming from motivational factors for the farmer. Factors empirically documented as drivers of cultivation of wheat and other cereals for ethanol production include aesthetic considerations and value arguments [18], opportunities to lease land for cultivation $[8,10]$, knowledge of cultivation methods, use of existing machinery [18], and better risk management from the perspective of the "crop basket" portfolio of the farm [11].

Hemp, on the other hand, is a very recent crop, and although annual and having fewer landscape effects than do cereals, thus enabling the provision of Common Agricultural Policy fallow subsidies [8], a number of motivational factors serve as barriers to its adoption. Legal restrictions, lack of knowledge of cultivation methods, costs of changing the production system, 
limited market opportunities, and no economies of scale are such factors found in the literature $[30,42]$.

The third crop, salix, is a perennial crop that has been grown in Sweden for energy purposes since the 1990s. The conversion from traditional food crops to salix is connected with several barriers, including the fact that it is perennial and requires new machinery [18]. Moreover, negative landscape effects and limited opportunities to lease land for salix production serves as barriers [18], as does the risk of damaging in field drainage. Several positive effects of salix, such as environmental considerations and improved hunting opportunities $[10,38]$, may serve as drivers for its adoption, and these are further supported by research and extension on cultivation methods [8].

The fourth crop, hybrid aspen, is a perennial crop only recently introduced into the production system in Sweden. No studies of this crop were found in our search that held information on the motivational factors constituting drivers and barriers. 
Table 3 - Drivers or barriers for four crops (annual/perennial and traditional/non-

traditional) among farmer in terms of values, legal, knowledge, and economic motivational

\section{factors}

\begin{tabular}{|c|c|c|c|c|c|}
\hline & & & & Peren & \\
\hline & Motivational & ENER & GRAIN & $S A L$ & \\
\hline & factors & Drivers & Barriers & Driver & Barriers \\
\hline$\overline{\mathrm{g}}$ & Values & $\begin{array}{l}\text { Attractive landscape } \\
{[11,18]}\end{array}$ & Fields for food [18] & $\begin{array}{l}\text { Landscape [38] } \\
\text { Hunting opportunities [39] } \\
\text { Reduced nutrient leaching [10, } \\
38] \\
\text { Less pesticides use[10] } \\
\text { Increased biodiversity [38] } \\
\text { Wind shelter against erosion } \\
\text { and snow [38] } \\
\text { Organic soil component } \\
\text { recovery [38] } \\
\text { Cadmium uptake [10] } \\
\text { High energy efficiency [40, 41] }\end{array}$ & $\begin{array}{l}\text { Attractive landscape [11, } \\
\text { 18] } \\
\text { Fields for food [18] } \\
\text { Greatly dependant on } \\
\text { fertilizers but in general } \\
\text { lower environmental } \\
\text { impact than annual crops } \\
\text { such as wheat [41] }\end{array}$ \\
\hline 章 & Legal & & & & $\begin{array}{l}\text { Tenure conditions for } \\
\text { perennial crops }[8,11 \text {, } \\
18]\end{array}$ \\
\hline & Knowledge & $\begin{array}{l}\text { Knowledge of } \\
\text { cultivation methods } \\
{[11,18]}\end{array}$ & & $\begin{array}{l}\text { Policy support (e.g., research } \\
\text { and extension) }[8,11]\end{array}$ & \\
\hline & Economy & $\begin{array}{l}\text { Risk management } \\
{[11]} \\
\text { Common Agricultural } \\
\text { Policy }[11,18] \\
\text { Alternative use of } \\
\text { land (i.e., fallow) }[8, \\
18,36]\end{array}$ & & $\begin{array}{l}\text { Economy of scale [11] and } \\
\text { vertical integration in the } \\
\text { biomass supply chain }[8,11 \text {, } \\
36] \\
\text { Existence and type of market } \\
\text { for output [8] } \\
\text { Contract farming as a } \\
\text { requirement for receiving } \\
\text { subsidies (salix) }[11,18]\end{array}$ & $\begin{array}{l}\text { Cost of changing } \\
\text { production system [18] } \\
\text { Alternative use of labour } \\
{[11,38]}\end{array}$ \\
\hline & & & & HYBRID & DEN \\
\hline & Values & $\begin{array}{l}\text { Appropriate for } \\
\text { ecological farming } \\
{[20]} \\
\text { Renewable fuel [31] }\end{array}$ & Fields for food [18] & & \\
\hline & Legal & & $\begin{array}{l}\text { Cultivation licence } \\
\text { [38] }\end{array}$ & & \\
\hline 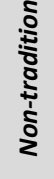 & Knowledge & An emerging field & $\begin{array}{l}\text { Lack of mechanical } \\
\text { equipment }[30,42] \\
\text { Little knowledge, e.g., } \\
\text { yield, harvest time, } \\
\text { and refinement [42] }\end{array}$ & & \\
\hline & Economy & $\begin{array}{l}\text { Alternative use of } \\
\text { land (i.e. fallow) [8] } \\
\text { Market for } \\
\text { briquetting [42] } \\
\text { Increased market } \\
\text { demand [30, 42] }\end{array}$ & $\begin{array}{l}\text { High production cost } \\
\text { [42] }\end{array}$ & & \\
\hline
\end{tabular}


Table 3 reveals that salix is a relatively well-researched energy crop, compared with both wheat and hemp, not to mention hybrid aspen. Studies often focus on a single crop [36, 43], or concentrate on a particular aspect of energy farming [38]. Very few studies take a more integrated perspective on a wider range of crop alternatives and motivational factors relevant to the farmer considering energy farming. This explains the many empty spaces in Table 3 compared with the wide range of motivational factors presented in Table 2. For each motivational factor and crop, a qualified hypothesis could be formulated regarding the direction of the effect on farmers' decisions (i.e., driver or barrier), but such hypotheses remain to be tested empirically. Moreover, the strength of various drivers and barriers, and their likely effects on different strata of the farming community, remain largely under researched. Rosenqvist et al. [43], for example, statistically analysed the characteristics of individual farmers who adopted salix cultivation, comparing this group with a strategic sample of farmers who did not. The only example of a more holistic study found in our body of literature is that of Paulrud and Laitila [18], who used a methodologically strict quantitative approach (i.e., a choice experiment) to investigate the effect of a limited number of motivational factors on a limited number of crops. Building a more comprehensive understanding of what affects farmer adoption of energy crops calls for a more explorative and qualitative approach.

The motivational factors discussed here were identified from the perspective of the individual farmer considering a conversion to energy crop cultivation. They all exert a direct influence on the in situ outcome, but often the motivational factors stem from trends and developments at the national or even global level. Energy crop production must be addressed using an integrated policy approach that incorporates energy, agriculture, forestry, and industrial policy [8]. The separation between proximate and underlying forces [19] may help sharpen the analysis. Thus, underlying driving forces, such as the Swedish government's desire to increase energy crop production and associated policies, such as a $\mathrm{CO}_{2}$ tax, indirectly influence farmers' decisions by increasing demand and thereby prices for energy crops $[8,36]$. Likewise, global food and energy prices affect farmers' choices through price signals. 


\section{DISCUSSION}

There is clearly a knowledge gap in our understanding of the various groups of motivational factors and how they are assessed by individual farmers. More specifically, this concerns the direction of motivational factors associated with various crops, their relative strengths, and whether different strata of farmers assess motivational factors differently, as well as the identification of proximate causes and underlying forces. As a first step toward filling this gap, an explorative investigation using focus groups of farmers and interviews with farm advisors, will be conducted in two Swedish agricultural regions as part of the K3 project. This qualitative approach may then be followed by a quantitative study, involving, for example, a multivariate contingent valuation or choice experiment analysis to identify the key factors or group of factors affecting farmers' choices.

The study also raises some questions regarding the adaptive capacity of the Swedish agricultural sector, which has long been considered in crisis, at least with regard to employment and earnings. Clearly, the opportunities created by increased national and global demand for energy crops enhance risk management and portfolio thinking for farmers, who can benefit from a wider choice of crops when deciding whether to stay in traditional food crop production or convert to energy crops. Strengthening this adaptive capacity still calls for a further improved understanding of the involved motivational factors to develop effective policies at the national and European levels.

On the other hand, increased global food prices, and the liberalization of energy markets (leading to reduced subsidies for pilot projects) may be underlying driving forces hampering the continued development of energy crop production. 


\section{CONCLUSIONS}

This analysis leads to the following conclusions;

- There are currently 13 energy crops available to Swedish farmers. The three most extensive energy crops produced in Sweden are straw (a residue), oil crops, and wheat, each covering between 15, 000-25, 000 ha.

- Although the economic incentives for changing production system are strong, factors concerning values, knowledge, and legal conditions are crucial for a change in production system.

- There has been no systematic investigation in the literature of why farmers decide to stay with a production system or change it, or of what motivational factors serve as drivers of or barriers to the cultivation of specific crops. To promote farmers to expand their production of energy crops, as stated by the Swedish Government and EU, this knowledge gap needs to be filled.

\section{ACKNOWLEDGEMENTS}

The paper is a product of the K3Jordbruk (see www.cspr.se) research project, funded by the Swedish Farmers' Foundation for Agricultural Research. The authors would like to thank the members of the project reference group for input during the process and particularly Robert Paulsson, Carin Gunnarsson, Göran Berndes and Helena Källström for productive information to the work and comments on the manuscript. We would also like to thank the reviewers for constructive comments. 


\section{REFERENCES}

[1] Communication from the Commission. Renewable energy road map renewable energies in the 21st century: Building a more sustainable future. COM (2006) 848 final (10.01.07)

[2] Directive 2009/28/EC. On the promotion of the use of energy from renewable sources and amending and subsequently repealing Directives 2001/77/EC and 2003/30/EC.2009.04.23. Off J European Union 2009.L 140: 16-62.

[3] Swedish Government Official Reports. Bioenergi från jordbruket - en växande resurs (Bioenergy from agridculture - a growing resource). Stockholm: Swedish Government; 2007. 492 pp. SOU 2007:36.

[4] Swedish Government Official Reports. Sverige inför klimatförändringarna - hot och möjligheter (Sweden and climate change - threats and potentials). Stockholm: Swedish Government; 2007. 721 pp. SOU 2007:60.

[5] UNFCCC. GHG inventory data/Detailed data by party/Sweden/All years/4.D - agriculture soil/Aggregate GHGs [cited 2011 March 25]. Available from:

http://unfccc.int/di/DetailedByParty/Event.do;jsessionid=71D22EB6AA7A==E1C75075 F558EBB504.diprod01? event $=$ go

[6] Swedish Environmental Protection Agency. National inventory report 2010. Submitted under the United Nations Framework Convention on Climate Change and the Kyoto Protocol [Internet]. Stockholm: Swedish Environmental Protection Agency; 2010. 295 pp [cited 2012 June 21]. Available from:

http://www.naturvardsverket.se/upload/05_klimat_i_forandring/statistik/2008/National \%20Inventroy\%20Report\%20(NIR\%20submission\%202010_Text.pdf

[7] Freibauer A. Regionalised inventory of biogenic greenhouse gas emissions from European agriculture. Eur J Agron 2003;19(2):135-160.

[8] Faaij APC. Bio-energy in Europe: Changing technology choices. Energy Policy 2006;34(3):322-342.

[9] Börjesson P. Environmental effects of energy crop cultivation in Sweden -I: Identification and quantification. Biomass Bioenerg 1999;16(2):137-154.

[10] Government of Sweden. Bioenergy from agriculture and forestry. Fact Sheet [Internet]. Stockholm: Ministry of Agriculture; 2008 - February. 2 pp [cited 2012 June 21]. Available from: http://www.sweden.gov.se/content/1/c6/09/94/68/86a44a1a.pdf.

[11] Berg M, Bubholz M, Forsberg M, Myringer Å, Palm O, Rönnbäck M, et al. Förstudiesammanställning och syntes av kunskap och erfarenheter om grödor från åker till energiproduktion [pre-study - compilation and synthesis of knowledge about energy crops from cultivation to energy production] [Internet]. Stockholm: Värmeforsk. 2007 - June. 149 pp. Report 1009 [cited 2012 June 21]. Available from: http://www.varmeforsk.se/rapporter?action=show\&id=1453 
[12] Berndes G, Magnusson L. The future of bioenergy in Sweden. Background and summary of outstanding issues. Eskilstuna: Swedish Energy Agency; 2006. 59 pp. ER 2006:30.

[13] The Federation of Swedish Farmers (LRF). De gröna näringarnas klimatlöfte [Internet] [cited 2010 April 13]. Available from: http://www.lrf.se/miljo/klimat/LRFs-klimatlofte

[14] Domac J, Richards K, Risovic S. Socio-economic drivers in implementing bioenergy projects. Biomass Bioenerg 2005;28(2):97-106.

[15] Ostwald M, Kuchler M. Climate science and policy research coming into being. Examples from the international politics of bioenergy and the case of avoided deforestation. In: Lövbrand E, Linnér B, Ostwald M, ed. Climate Science and Policy Research. Conceptual and Methodological Challenges. Linköping: Centre for Climate Science and Policy Research; 2009. 12 pp. CSPR Report 2009:03.

[16] Kuchler M. Unravelling the argument for bioenergy production in developing countries: A world-economy perspective. Ecol Econ 2010;69(6):1336-1343.

[17] Gomiero T, Paoletti MG, Pimentel D. Biofuels: Efficiency, ethics, and limits to human appropriation of ecosystem services. J Agricultural and Environmental Ethics 2010;23(5):403-434.

[18] Paulrud S, Laitila T. Lantbrukarnas attityder till odling av energigrödor. Värderingsstudie med choice experiment. [Farmers' attitudes to cultivating energy crops. Perception study with choice experiment] [Internet]. Stockholm: IVL Swedish Environmental Research Institute; 2007. 57 pp [cited 2012 June 21]. Available from:

http://www.energimyndigheten.se/Global/Forskning/Bränsle/AttityderTillEnergigrodor _IVL_07.pdf

[19] Ostwald M, Wibeck V, Stridbeck P. Proximate causes and underlying driving forces of landuse change among small-scale farmers-illustrations from the loess plateau, china. Journal of Land Use Science 2009;4(3):157-171.

[20] Swedish Board of Agriculture. Bioenergi- ny energi för jordbruket [Bioenergy - a new energy from agriculture]. Jönköping: Swedish Board of Agriculture; 2006. 81 pp. Rapport 2006:1.

[21] Lantz M, Svensson M, Björnsson L, Börjesson P. The prospects for an expansion of biogas systems in Sweden--incentives, barriers and potentials. Energy Policy 200;35(3):18301843.

[22] Grob A. A structural model of environmental attitudes and behaviour. J Environ Psychol 1995;15(3):209-220.

[23] Nicholson-Cole SA. Representing climate change futures: A critique on the use of images for visual communication. Comput , Environ Urban Syst 2005;29(3):255-273.

[24] Kollmuss A, Agyeman J. Mind the gap: Why do people act environmentally and what are the barriers to pro-environmental behavior? Environmental Education Research 2002;8(3):239-260.

[25] Moser SC, Dilling L. Making climate hot. Environment: Science and Policy for Sustainable Development 2004;46(10):32-46. 
[26] Trudgill ST. Barriers to a better environment: What stops us solving environmental problems? London: Belhaven press; 1990.

[27] Belausteguigoitia JC. Causal chain analysis and root causes: The GIWA approach. AMBIO: A Journal of the Human Environment 2004;33(1):7-12.

[28] Blennow, K. and Persson, J. Climate change: Motivation for taking measure to adapt. Global Environ Change 2009;19(1):100-104.

[29] Börjesson P. Energianalys av drivmedel från spannmål och vall [Energy analysis of fuels from grain and crops] [Internet]. Lund: Lunds Tekniska Högskola; 2004. 13 pp. Rapport 2004:54 [cited 2012 June 21]. Available from:

http://www.miljo.lth.se/svenska/internt/publikationer_internt/pdf-

filer/etanolochbiogas.pdf

[30] Sundberg, M. and Westin, H. Hampa som bränsleråvara [Hemp as a fuel - pre-study] [Internet]. Uppsala: JTI; 2005. 29 pp. JTI Rapport 341 [cited 2012 June 21]. Available from: http://www.jti.se/uploads/jti/R-341MS.pdf

[31] Flodin P. Hampa som energigröda. [Hemp as an energy crop] [Internet]. Göteborg: Department of Physics, Gothenburg University; 2005. 7 pp [cited 2012 June 21]. Available from: http://fy.chalmers.se/ f5xrk/Hampa.pdf

[32] Kimming M. Investigating potential contract models to stimulate commercial production of energy crops. Risk Perceptions and Risk Reduction Options for Agro-Biofuel Production in Sweden, France and Finland [Internet]. Lund University; 2008. 81 pp. IIIEE Theses 2008:10 [cited 2012 June 21]. Available from: http://www.uppsatser.se/uppsats/e6063f5326/

[33] LRF, The Federation of Swedish Farmers. Kartläggning av medlemmarnas energiverksamheter [Internet]. Questionnaire survey, Powerpoint presentation. 2009 [cited 2012 June 21]. Available from:

http://www.Irf.se/PageFiles/18385/Rapport_LRF_Energi_maj2009_TOTAL.pdf

[34] Börjesson P. Produktionsförutsättningar för biobränslen inom svenskt jordbruk [Requirements for produciton of bioenergy within swedish agriculture] [Internet]. Lund: Lunds Tekniska Högskola; 2007. 87 pp. Rapport 2007:61 [cited 2012 June 21]. Available from:

http://lup.lub.lu.se/luur/download?func=downloadFile\&recordOId=604789\&fileOId=6091 51

[35] Helby P, Rosenqvist H, Roos A. Retreat from salix-swedish experience with energy crops in the 1990s. Biomass Bioenerg 2006;30(5):422-427.

[36] Hillring B. Rural development and bioenergy-experiences from 20 years of development in sweden. Biomass Bioenerg 2002;23(6):443-451.

[37] Ministry of Rural Affairs. Förordning om stöd för landsbygdsutvecklingsåtgärder [Regulation on support for rural development measures.]. Stockholm: Svensk författningssamling; 2007. Förordning 2007:481.

[38] Skärbäck E, Becht P. Landscape perspective on energy forests. Biomass Bioenerg 2005;28(2):151-159. 
[39] K3. Project reference group meeting September. 2009. Oral information.

[40] Börjesson P. Energibalans för bioetanol-en kunskapsöversikt [Energy balance - a knowledge overview] [Internet]. Lund: Lunds Tekniska Högskola; 2006 - March. 17 pp. Rapport 2006:59 [cited 2012 June 21]. Available from: http://www.besteurope.org/upload/BEST_documents/environment/Börjesson\%20-\%20Bioetanol.pdf

[41] Börjesson P. Livscykelanalys av Salixproduktion [Life cycle assessment of willow production] [Internet]. Lund: Lunds Tekniska Högskola; 2006 - March. 21 pp. Rapport 2006:60 [cited 2012 June 21]. Available from: http://www.miljo.lth.se/svenska/internt/publikationer_internt/pdffiler/LCA\%20av\%20Salixproduktion-IMES\%20Rapport\%2060.pdf

[42] Forsberg M, Sundberg, M. and Westlin, H. Småskalig brikettering av hampa- förstudie [Small scale briquette production from hemp - prestudy] [Internet]. Uppsala: JTI; 2006. 31 pp. JTI Rapport 351 [cited 2012 June 21]. Available from: http://www.jti.se/uploads/jti/R351-MF,MS,HW.pdf

[43] Rosenqvist H, Roos A, Ling E, Hektor B. Willow growers in sweden. Biomass Bioenerg 2000;18(2):137-145. 